\title{
Development of Single Chamber Solid Oxide Fuel Cells (SCFC)
}

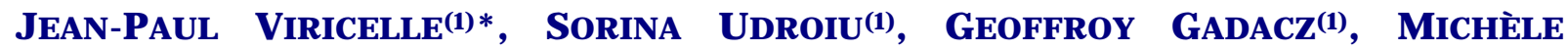 \\ Pij Olat ${ }^{(1)}$, Christophe Pij OLAT ${ }^{(1)}$
}

(1) Ecole Nationale Supérieure des Mines de Saint Etienne, Centre SPIN ; Département MICC \& ProcESS; LPMG -UMR CNRS 5148, 158 Cours Fauriel ; 42023 Saint-Étienne Cedex 2, France

\begin{abstract}
Single Chamber Solid Oxide Fuel Cells (SCFC) have been prepared using an electrolyte as support $\left(\mathrm{Ce}_{0.9} \mathrm{Gd}_{0.1} \mathrm{O}_{1.95}\right.$ named GDC). Anode (Ni-GDC) and different cathodes $\left(\mathrm{Sm}_{0.5} \mathrm{Sr}_{0.5} \mathrm{CoO}_{3}\right.$ (SSC), $\mathrm{Ba}_{0.5} \mathrm{Sr}_{0.5} \mathrm{Co}_{0.2} \mathrm{Fe}_{0.8} \mathrm{O}_{3}$ (BSCF) and $\mathrm{La}_{0.8} \mathrm{Sr}_{0.2} \mathrm{MnO}_{3}$ (LSM)) were placed on the same side of the electrolyte. All the electrodes were deposited using screenprinting technology. A gold collector was also deposited on the cathode to decrease the over-potential. The different materials and fuel cell devices were tested under propane/air mixture, after a preliminary treatment under hydrogen to reduce the as-deposited nickel oxide anode. The results show that SSC and BSCF cathodes are not stable in these conditions, leading to a very low open circuit voltage (OCV) of $150 \mathrm{mV}$. Although LSM material is not the more adequate cathode regarding its high catalytic activity towards hydrocarbon conversion, it has a better chemical stability than SSC and BSCF. Ni-GDC-LSM SCFC devices were elaborated and tested; an OCV of nearly $750 \mathrm{mV}$ could be obtained with maximum power densities around $20 \mathrm{~mW} \mathrm{~cm} \mathrm{~cm}^{-2}$ at $620{ }^{\circ} \mathrm{C}$, under air- propane mixture with $\mathrm{C}_{3} \mathrm{H}_{8} / \mathrm{O}_{2}$ ratio equal to 0.53.
\end{abstract}

Keywords:

BSCF ; Fuel Cell ; GDC ; LSM ; Single Chamber ; SOFC ; Solid Oxide Fuel Cell ; SSC.

\section{Introduction}

Solid oxide fuel cells (SOFC) have been studied intensively over the past two decades. Main efforts deal with the reduction of working temperature from 1,000 to around $600{ }^{\circ} \mathrm{C}$ in order to reduce the cost due to the requirement of robust materials with adequate electrical and electrochemical properties, thermal stability and due to the technological problems, especially sealing between anodic and cathodic chambers.More recently, a new type of device named 'Single Chamber Solid Oxide Fuel Cells' (SCFC) has been proposed. In such device, contrary to conventional SOFC, anode and cathode are exposed to a gas mixture of fuel (hydrocarbon) and oxidant (air) so that no more sealing with electrolyte is necessary. Their operating principle is based on the different catalytic activities of anode and cathode: ideally, the anode has to be active for the oxidation of fuel while the cathode should only present a strong electro-activity for oxygen reduction. Most significant and initial developments of SCFC devices were performed by Hibino and co-workers who proposed a review on SCFC in Reference [1]. In the first development of SCFC devices [2- 4], materials used in conventional SOFC were used, namely YSZ for electrolyte, Ni-YSZ cermet anode and LSM ( $\left.\mathrm{La}_{0.8} \mathrm{Sr}_{0.2} \mathrm{MnO}_{3}\right)$ cathode. As for conventional SOFC, such materials are now more and more replaced in order to significantly reduce the operating temperature while increasing or, at least maintaining performances. YSZ electrolyte is substituted by doped ceria oxide either with Gadolinium

\footnotetext{
* Auteur à qui la correspondance devait être adressée : viricelle@emse.fr
} 
(GDC) or samarium (SDC). Most of the anodes are constituted by a cermet of previous electrolyte with nickel. For cathode, the trend is to use doped perovskites with cobalt, either $\mathrm{Ba}_{0.5} \mathrm{Sr}_{0.5} \mathrm{Co}_{0.8} \mathrm{Fe}_{0.2} \mathrm{O}_{3-\mathrm{d}}$ (BSCF, [5]) or $\mathrm{Sm}_{0.5} \mathrm{Sr}_{0.5} \mathrm{CoO}_{3}$ (SSC, [6- 8]), or $\mathrm{La}_{0.5} \mathrm{Sr}_{0.5} \mathrm{CoO}_{3}$ (LSC, [9]). With such SCFC devices, depending on the cell microstructure, geometry and flow conditions, maximum power densities of $700 \mathrm{~mW} \mathrm{~cm}^{-2}$ at $600{ }^{\circ} \mathrm{C}$ have been reached [7]. However, such high values are not so easily obtained: even for fixed materials, all experimental details such as flow geometry [8] or the way of the SCFC initialisation [10] for example, have significant influence on the performances.

The aim of this study was to investigate the influence of experimental parameters, especially flow composition, in our testing bench conditions. More comprehensive studies on SCFC working principle were reported by Hibino and coworkers [1] and Haile and co-workers [7]. In the present paper, we present our recent results concerning SCFC developments, with GDC electrolyte, Ni-GDC anode and LSM or SSC or BSCF as cathode. Materials characterisations and SCFC evaluations were performed under propane/ oxygen mixtures. Among possible hydrocarbons, propane was chosen because it can be cracked at lower temperature than methane, and it can also produce more hydrogen by partial oxidation due to its higher carbon number (Equation (1)).

$$
2 \mathrm{C}_{3} \mathrm{H}_{8}+3 \mathrm{O}_{2} \rightarrow 6 \mathrm{CO}+8 \mathrm{H}_{2}
$$

\section{Experimental}

\section{II.1. Materials, SCFC Preparation}

The electrolyte material was made using a starting commercial powder ( ${ }^{\circledR}$ NexTech Materials $\mathrm{Ltd}$ ) of gadolinium doped ceria $\left(\mathrm{Ce}_{0.9} \mathrm{Gd}_{0.1} \mathrm{O}_{1.95}\right.$ named GDC), having a specific area around 9 $\mathrm{m}^{2} \mathrm{~g}^{-1}$. The particle size is in the range $0.1-10 \mu \mathrm{m}$ with a mean size $\left(\mathrm{d}_{50}\right)$ around $0.5 \mu \mathrm{m}$. The powder was pressed into pellets (100 MPa, $2 \mathrm{~min}$ ) and sintered at 1,350 ${ }^{\circ} \mathrm{C}$ for $4 \mathrm{~h}$ with an intermediate step at $1,200^{\circ} \mathrm{C}$ during $6 \mathrm{~h}$. Temperature rates were $10^{\circ} \mathrm{C} \mathrm{min}-1$ for both heating and cooling. Final pellets have a diameter of $19 \mathrm{~mm}$ and a thickness of $0.8 \mathrm{~mm}$. Their relative density is around $92 \%$.

Anode cermet was prepared from a mixture of 60 wt\% NiO (Sigma-Aldrich) and 40 wt\% GDC. The initial NiO powder having a specific area around 3-4 $\mathrm{m}^{2} \mathrm{~g}^{-1}$ was strongly agglomerated and was ball-milled in ethanol. The solvent was then evaporated while stirring and the resulting powder was passed through a $100 \mu \mathrm{m}$ screen sieve. The $\mathrm{NiO}$ powder particles size was then comparable to the one of GDC powder. The two powders were then mixed and ground in a mortar and pestle. Then, commercial binder and solvent were added to obtain an ink for screen-printing. The ink was homogenised with an ${ }^{\circledR}$ Ultra-Turrax dispersion tool. The anode layer of $6 \times 6 \mathrm{~mm}^{2}$ was then deposited by screen-printing technology on the previously described GDC pellet. To study the influence of electrode thickness, the number of deposited layer was varied, with an intermediate drying step at $130{ }^{\circ} \mathrm{C}$ during $10 \mathrm{~min}$ between each deposit. The deposited films were fired at $1,200{ }^{\circ} \mathrm{C}$ for $2 \mathrm{~h}$, resulting in a porous anode layer with a thickness of either around $10 \mu \mathrm{m}$ (1 layer), $20 \mu \mathrm{m}$ (2 layers) or $40 \mu \mathrm{m}$ (4 layers). In order to activate the anode, reduction of nickel oxide was performed by thermal treatment in hydrogen. This part is detailed in Section III.1.

Cathode was prepared using a similar process as for the anode. The powders were passed though a $100 \mathrm{Im}$ screen sieve, and then mixed with a binder and a solvent to obtain an ink. Cathode layers were also deposited using screen-printing. Three materials were used: $\mathrm{La}_{0.8} \mathrm{Sr}_{0.2} \mathrm{MnO}_{3}$ (named LSM) and $\mathrm{Sm}_{0.5} \mathrm{Sr}_{0.5} \mathrm{CoO}_{3}$ (named SSC), commercial powders from Nex-Tech Materials Ltd, and an in-house powder supplied by IRCELYON laboratory (France), $\mathrm{Ba}_{0.5} \mathrm{Sr}_{0.5} \mathrm{Co}_{0.2} \mathrm{Fe}_{0.8} \mathrm{O}_{3}$ (named BSCF). Considering their thermal stability, these cathodes were fired at $1,200,1,000$ and $950{ }^{\circ} \mathrm{C}$ for LSM, BSCF and SSC, respectively. Anode and cathode were successively deposited and fired as reported previously, on the same side of the electrolyte pellet. The space between the two square electrodes is around $1 \mathrm{~mm}$. For SCFC performances tests, a gold current collector was deposited on the cathode. These collectors consist in a grid (line space of $0.5 \mathrm{~mm}$ ) deposited by screen-printing, using a commercial gold 
paste. It was fired after deposition, at $900{ }^{\circ} \mathrm{C}$ during $20 \mathrm{~min}$. An SCFC prototype can be seen in Figure 1.

\section{II.2. Material Characterisation, Fuel Cell Performance Test}

Prior to fuel cell performances tests, materials were characterised in regards of their electrical conductivity, catalytic activity and thermal stability.

Electrical conductivity of anode and cathode was measured according to Van Der Pauw method [11]. Particular samples supporting only the anode or the cathode on the GDC pellet were prepared, using the same elaboration process and parameters as described in previous part. Four thin platinum wires were stuck to the border of the studied layer with a platinum paste. These wires were connected to conventional electrical equipment to monitor current and voltage according to Van Der Pauw methodology. For cathode materials, measurements were conducted in air in the range $20-600{ }^{\circ} \mathrm{C}$. For anode, to avoid nickel re-oxidation, airpropane mixture was set in the bench after the reduction process made in hydrogen.

Catalytic activity of cathode materials was investigated in a fixed bed reactor, towards propane conversion. The same quantity of cathode material in the form of powder dispersed in alumina was introduced to have comparative results. Propane conversion was measured. Propane conversion was measured thanks to a mass spectrometer coupled with a micro-gas chromatograph (IGC-MS) placed at the bench outlet. Effectively, as the SCFC principle is based on the difference of catalytic activity of anode and cathode, cathode materials have to be the less active as possible with the hydrocarbon; they should only present a strong electrochemical activity towards oxygen reduction.

Anode and cathode thermal stability was investigated in the SCFC running conditions, after exposure to air-propane mixtures, by X-ray diffraction. For cathodes, same characterisations were performed after the hydrogen treatment of the anode in order to control if they can withstand it.

SCFC performances were measured in a simple test bench consisting in a tubular furnace with a quartz tube. Electrical contacts are achieved thanks to gold wires in mechanical contact with gold collector on the cathode, and directly on the anode. In situ activation of the anode was performed under a gas flow of $2 \%$ hydrogen balanced with argon. Then, after purging the system with nitrogen, the propane-air mixture was introduced. Three parameters were mainly investigated: total gas flow, $\mathrm{C}_{3} \mathrm{H}_{8} / \mathrm{O}_{2}$ ratio and the temperature. The gas flow was varied in the range 15-50 $\mathrm{L} \mathrm{h}^{-1}$ : it is constituted of air-propane mixture and, for safety reasons, of an additional nitrogen flow in order to decrease the oxygen content to $12 \%$ in the bench. For example, total gas flow of $45 \mathrm{~L} \mathrm{~h}^{-1}$ was composed of $30 \mathrm{~L} \mathrm{~h}^{-1}$ of air-propane mixture and $15 \mathrm{~L} \mathrm{~h}^{-1}$ of nitrogen. Effectively, in air, the explosive domain of air-propane mixtures is in the range $2.2-10 \%$ of propane. The decrease of oxygen content reduces this area which disappears for oxygen content lower than $12 \%$. Another important parameter is air-propane ratio which was investigated in the range $10-16 \mathrm{vol} \%$ in propane, corresponding, respectively, to $\mathrm{C}_{3} \mathrm{H}_{8} / \mathrm{O}_{2}$ ratio in the range 0.53- 0.95. It must be noted that the corresponding ratio for partial oxidation of propane (Equation (1)) is 0.66. SCFC were tested in the temperature range $580-650{ }^{\circ} \mathrm{C}$. These temperatures correspond to the regulated value of the furnace; depending on gas conditions, strong exothermic effect (overshoot of around $50{ }^{\circ} \mathrm{C}$ ) can occur during propane oxidation. If not specified, the reported temperatures are the furnace temperatures. A gas chromatograph and an infrared gas analyser performed gas analysis at the outlet of the test bench. The polarisation curves of the SCFC devices were simultaneously measured in order to correlate performances with experimental conditions.

\section{Results}

\section{III.1. Anode Characterisation}

\section{III.1.1. Anode Reduction}

The as-prepared NiO-CGO cermet anode has to be reduced before use in SCFC device. As in situ reduction in air-propane mixture could not be easily achieved, a pre-treatment in $\mathrm{H}_{2}$ ( $2 \%$ balanced in $\mathrm{Ar}$ ) was conducted. In order to define the adequate temperature range, 
thermogravimetric experiments were conducted with $\mathrm{NiO}$ and GDC powders. These powders were previously fired in air at $1,200{ }^{\circ} \mathrm{C}$ during $2 \mathrm{~h}$, as done for the screen-printed layers. Results reported in Figure 2 show that $\mathrm{NiO}$ begins to reduce at around $400{ }^{\circ} \mathrm{C}$, with a total reaction reached around $800{ }^{\circ} \mathrm{C}$ corresponding to the theoretical weight loss of $21.4 \%$. For GDC, a significant weight loss attributed to partial reduction of cerium IV in cerium III is observed from $600{ }^{\circ} \mathrm{C}$.

Taking into account previous results, various reduction conditions of the anode in the same gas have been tested in the temperature range $400-600{ }^{\circ} \mathrm{C}$, with varying duration from 30 min to few hours. Optimum condition to obtain a total reduction of $\mathrm{NiO}$ in our test bench, as shown by X-ray diffraction analysis (Figure 3), was found for a treatment of $600{ }^{\circ} \mathrm{C}$ during 30 $\min$.

\section{III.1.2. Anode Conductivity}

In order to check if the Ni-GDC anode has a satisfying electronic conductivity, conductivity measurements were performed as described in Section II.2. Results can be seen in Figure 4. Immediately after reduction at $600{ }^{\circ} \mathrm{C}$, the anode is stabilised under a nitrogen flow and the temperature is decreased to $520{ }^{\circ} \mathrm{C}$. During this period (domain (a) in Figure 4), the conductivity is quite high around $900 \mathrm{~S} \mathrm{~cm}^{-1}$.

However, as soon as nitrogen is replaced by the flow of air- propane $\left(\mathrm{C}_{3} \mathrm{H}_{8} / \mathrm{O}_{2}\right.$ ratio equal to 0.66), at $520{ }^{\circ} \mathrm{C}$, the conductivity begins to decrease (domain b). The temperature is then raised to $535{ }^{\circ} \mathrm{C}$, and step by step up to $570{ }^{\circ} \mathrm{C}$. At $535^{\circ} \mathrm{C}$, the conductivity comes back to its initial value and keeps a nearly constant and high value in the range $535-570{ }^{\circ} \mathrm{C}$ (domain c).

Same experiment (not shown in Figure 4) was done with decreasing temperature and a similar behaviour was observed. At temperature lower than $530{ }^{\circ} \mathrm{C}$, the conductivity begins to collapse. After cooling back to room temperature, a green colour of the anode was observed at the surface, indicating a re-oxidation of nickel. These results validate the preparation process of the anode, but indicate that, for SCFC operating in our experimental conditions, temperature must be kept higher than $520{ }^{\circ} \mathrm{C}$ to avoid nickel re-oxidation. A thermodynamic study was performed to check these experimental observations.

A good agreement was obtained: calculations of the free Gibbs energy indicate that, among possible reactions of nickel and nickel oxide in the studied system, the predominant reaction at temperature lower than $535{ }^{\circ} \mathrm{C}$ is the re-oxidation of nickel (Equation (2)). At higher temperature, reduction of nickel oxide by propane is favoured (Equation (3)).

$$
\begin{aligned}
& \mathrm{Ni}+1 / 2 \mathrm{O}_{2} \rightarrow \mathrm{NiO} \\
& 1 / 3 \mathrm{C}_{3} \mathrm{H}_{8}+\mathrm{NiO} \rightarrow \mathrm{Ni}+\mathrm{CO}+4 / 3 \mathrm{H}_{2}
\end{aligned}
$$

\section{III.2. Cathode Characterisation}

\section{III.2.1. Cathode Conductivity}

Electrical conductivity of the three studied cathode material, LSM, SSC and BSCF was measured under air in the range $20-600{ }^{\circ} \mathrm{C}$. Values reported in Figure 5 point out that SSC is the more conducted cathode with conductivity around $650 \mathrm{~S} \mathrm{~cm}^{-1}$ at $600{ }^{\circ} \mathrm{C}$. The value for LSM and BSCF are, respectively, around 130 and $10 \mathrm{~S} \mathrm{~cm}^{-1}$ at $600{ }^{\circ} \mathrm{C}$. The difference of electrical conductivity and especially the low value measured for BSCF cathode may be explained by the morphology of the layers: SEM observations (Figure 6) clearly point out that BSCF layer is quite more porous than SSC and LSM layers.

\section{III.2.2. Cathode Catalytic Activity}

As reported previously, the efficiency of a cathode in a SCFC device is based on its low catalytic activity in regards of hydrocarbon conversion. Figure 7 represents propane conversion measured by the $\mu \mathrm{GC}$-MS equipment at the outlet of the catalytic test bench versus temperature, for the three studied cathode material. Gas composition was set at a $\mathrm{C}_{3} \mathrm{H}_{8} / \mathrm{O}_{2}$ ratio equal to 0.66 , thus corresponding to stoichiometric conditions of partial oxidation (Equation (1)). Results show a strong catalytic activity of LSM and SSC material in the range 450-600 ${ }^{\circ} \mathrm{C}$, quite higher than the one of BSCF. For this material, propane conversion 
increase slowly versus temperature but remains lower than $20 \%$ at $600{ }^{\circ} \mathrm{C}$, whereas it reaches, respectively, around 50 and $80 \%$ for SSC and LSM. Hence, considering catalytic activity criteria, BSCF is the more adequate cathode material for SCFC device.

\section{III.2.3. Cathode Thermal Stability}

Although interesting performances have been obtained with the studied cathode materials used in SCFC, the problem of SSC and BSCF stability has been reported previously $[9,10]$. Hence, it is necessary to investigate the thermal stability of the three cathode materials both in hydrogen (conditions of anode reduction) and air-propane (SCFC test conditions) gas flow. After a thermal treatment similar to the anode reduction one, $600{ }^{\circ} \mathrm{C}$ during 30 min in $\mathrm{H}_{2}(2 \%$ balanced in Ar), SSC and BSCF materials are degraded (Figure 8 for SSC). In similar conditions (30 min in $\mathrm{H}_{2}$ ), LSM material is stable according to XRD analysis. Then, the stability of the three cathodes was also investigated in air-propane mixture at $630{ }^{\circ} \mathrm{C}$, without prior exposure to the reduction pretreatment in hydrogen. Effectively, other processes have been proposed in the literature [10] to avoid anode initialisation by hydrogen pretreatment, in order to prevent cathode degradation. However, in our conditions, SSC and BSCF materials still present degradation, even if it appears less drastic than in hydrogen. LSM did not present any degradation in the same conditions. In our actual preparation process of the SCFC device, both anode and cathode are deposited on the GDC support before the anode reduction treatment. Moreover, long-term stability of BSCF and SCC materials is questionable in airpropane mixtures, at least in our experimental conditions. Hence, for the present study, it was only possible to use LSM material as a cathode, although we have confirmed that it is not the more adequate one, in regards of a too high catalytic activity for propane conversion.

\section{III.3. (Ni-CGO/CGO/LSM) SCFC Performance Tests}

\section{III.3.1. Preliminary Tests with a 20 /m Thick Anode}

SCFC devices were tested in our bench as described in Section II.2. Preliminary tests were conducted with the sample prepared with a $20 \mu \mathrm{m}$ thick anode, a $\mathrm{C}_{3} \mathrm{H}_{8} / \mathrm{O}_{2}$ ratio equal to 0.55 and a total flow of $45 \mathrm{~L} \mathrm{~h}^{-1}$. Typical variation of the open circuit voltage (OCV) versus time and sample temperature can be seen in Figure 9. After the in situ reduction of the anode at $600^{\circ} \mathrm{C}$, the sample temperature is set at $580{ }^{\circ} \mathrm{C}$ and the air-propane mixture is introduced. At this temperature, the OCV is quite low, in the range $100-200 \mathrm{mV}$. Then, the temperature is increased to find the optimum value corresponding to the highest OCV. Figure 9 shows that the OCV increases sharply from around $620^{\circ} \mathrm{C}$ with also increasing exothermic effect, but the OCV presents some strong oscillations. It tends to stabilise around $500 \mathrm{mV}$ at $700{ }^{\circ} \mathrm{C}$ (sample temperature; furnace is at around $650{ }^{\circ} \mathrm{C}$ ). If the temperature is more increased, a sudden reduction of OCV value is observed, which is reversible with temperature decrease. Hence, for this sample (20um thick anode) and in the present experimental conditions, the optimum sample temperature is $700{ }^{\circ} \mathrm{C}$. In a previous paper [12], we have shown that the optimal conditions are strongly dependant on experimental parameters. Voltage-current characteristic measured at these optimum conditions for this sample is reported in Figure 10. The effective area considered for calculation of current and power densities, taking into account our planar geometry (Figure 1), is the section of the electrolyte between the two electrodes, equal to $4.8 \mathrm{~mm}^{2}\left(6 \times 0.8 \mathrm{~mm}^{2}\right)$. A maximum power density of around $10 \mathrm{mWcm}^{-2}$ is obtained. Characterisations of anode and cathode materials after the SCFC evaluation with various conditions were carried out by X-ray diffraction. For LSM, no significant modification could be detected. For Ni-CGO anode, results are more various depending on the history of the SCFC device. A partial nickel re-oxidation is sometimes observed, but it is not clear if it occurs during the fuel cell test, or during cooling down to ambient after test, which would be in agreement with observations made during anode conductivity characterisation (Section III.1.2). In other conditions, especially higher $\mathrm{C}_{3} \mathrm{H}_{8} / \mathrm{O}_{2}$ ratio $(0.95)$, carbon deposition is observed on the anode. 


\section{III.3.2. Influence of Experimental Parameters on Outlet Gas Composition}

The influence of $\mathrm{C}_{3} \mathrm{H}_{8} / \mathrm{O}_{2}$ ratio and of total gas flow was investigated in more details thanks to

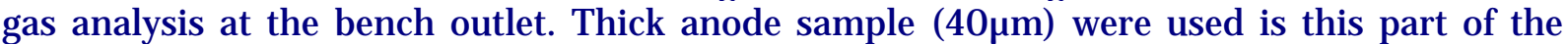
study. For this sample, the optimum SCFC temperature was shifted to $620{ }^{\circ} \mathrm{C}$ in conditions similar to previous ones $\left(\mathrm{C}_{3} \mathrm{H}_{8} / \mathrm{O}_{2}\right.$ ratio equal to 0.55 and a total flow of $\left.45 \mathrm{~L} \mathrm{~h}^{-1}\right)$. Hence, this sample temperature was fixed for following tests. Influence of $\mathrm{C}_{3} \mathrm{H}_{8} / \mathrm{O}_{2}$ ratio with a fixed total flow of $45 \mathrm{~L} \mathrm{~h}^{-1}$ is shown in Figure 11. The concentration (vol\%) of main constituents detected by the gas chromatograph are reported. Taking into account that the desired reaction is partial oxidation for $\mathrm{CO}$ and $\mathrm{H}_{2}$ production (Equation (1)), comments are focused on these gases. Figure 11 shows that, with increasing $\mathrm{C}_{3} \mathrm{H}_{8} / \mathrm{O}_{2}$ ratio, $\mathrm{CO}$ and $\mathrm{H}_{2}$ production decreases, contrary to concentrations of propane conversion sub-products. SFC performances were also observed to decrease, both OCV and power densities with increasing $\mathrm{C}_{3} \mathrm{H}_{8} / \mathrm{O}_{2}$ ratio, starting from a value of 0.53 . The influence of total gas flow in the range $12-45 \mathrm{~L} \mathrm{~h}^{-1}$ was then investigated at $620{ }^{\circ} \mathrm{C}$ and $\mathrm{C}_{3} \mathrm{H}_{8} / \mathrm{O}_{2}$ ratio fixed at 0.53 . Figure 12 indicates that $\mathrm{CO}$ and $\mathrm{H}_{2}$ production increases with increasing flow higher than $25 \mathrm{~L} \mathrm{~h}^{-1}$. The same trend was also observed for SCFC performances. The polarisation curve measured for our optimum conditions, $620{ }^{\circ} \mathrm{C}, \mathrm{C}_{3} \mathrm{H}_{8} / \mathrm{O}_{2}$ ratio 0.53 and total gas flow of $45 \mathrm{~L} \mathrm{~h}^{-1}$ can be seen in Figure 13 . Main curve is obtained with a $40 \mathrm{Im}$ thick anode, while the insight shows measurements performed with a device having a $10 \mu \mathrm{m}$ thick anode. For the first one (40 $\mu \mathrm{m}$ thick anode), $\mathrm{OCV}$ is around $780 \mathrm{mV}$, and the maximum power density reaches $18 \mathrm{~mW} \mathrm{~cm}{ }^{-2}$. Hence performances are improved compared to previous tested device with a 20um thick anode (Figure 10). Moreover, insight of Figure 13 shows that the 10um thick anode device exhibits almost no more power density $\left(0.035 \mathrm{~mW} \mathrm{~cm}^{-2}\right)$. Observations of SCFC samples tested in our

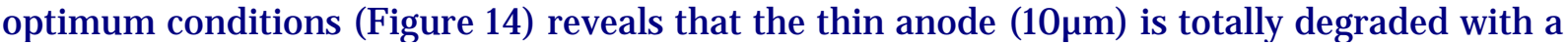
black colour compared to grey colour of safe nickel anode. Strong exothermic effect due to high anode reactivity can explain this phenomenon. Hence, for fixed gas conditions (composition, flow), the thickness of the anode is of crucial importance for SCFC performances.

\section{Conclusion}

An SCFC device with a simple coplanar geometry of the electrodes was developed. The feasibility of operating in air-propane mixture was confirmed. However, with the actual configuration of SFC device (LSM-GDC-Ni) and test bench (furnace and gas feed geometry), limited performances were recorded. The maximum power density that we could obtain is around $20 \mathrm{~mW} \mathrm{~cm}^{-2}$. Considering the too high catalytic activity of LSM towards hydrocarbon conversion, and the low studied temperature around $600{ }^{\circ} \mathrm{C}$, SSC and BSCF cathode materials should lead to higher performances compared to LSM. However, stability of SSC and BSCF materials in air-propane mixtures could be hardly achieved. For nickel anodes, in our test conditions, a minimum temperature of $535{ }^{\circ} \mathrm{C}$ was required to avoid its re-oxidation. Moreover, a minimum thickness is also probably required, regarding strong exothermic effects during propane oxidation. In order to improve SCFC performances, investigations on anode behaviour in running conditions is still continued, and modelling of the reactor geometry and chemical reactions rates around cathode and anode is required to optimise the experimental conditions.

\section{References}

[1] M. Yano, A. Tomita, M. Sano, T. Hibino, Solid State Ionics 2007, 177, 3351.

[2] T. Hibino, S. Wang, S. Kakimoto, M. Sano, Solid State Ionics 2000, 127, 89.

[3] T. W. Napporn, X. J acques-Bédart, F. Morin, M. Meunier, J. Electrochem. Soc. 2004, 151, A2088.

[4] D. Rotureau, J .-P. Viricelle, C. Pijolat, N. Caillol, M. Pijolat, J. Eur. Ceram. Soc. 2005, 25, 2633.

[5] Z. Shao, J. Mederos, W. C. Chueh, S. M. Haile, J. Power Sources 2006, 162, 589. 
[6] L. J. Gauckler, J. Power sources 2007, 171, 310.

[7] Y. Hao, Z. Shao, J. Mederos, W. Lai, D. G. Goodwin, S. Haile, Solid State Ionics 2006, 2013.

[8] I. C. Stefan, C. P. J acobson, S. J . Visco, L. C. De J onghe, Electrochem Solid State Lett. 2004, 7, A198.

[9] M. Morales, S. Pinol, M. Segarra, J. Power Sources 2009, 194, 961.

[10] C. Zhang, Y. Zheng, R. Ran, Z. Shao, W. J in, N. Xu, J. Ahn, J. Power Sources 2008, 179, 640.

[11] . Van Der Pauw, Philips Res. Rep. 1958, 13, 1.

[12] J. P. Viricelle, C. Pijolat, B. Riviere, D. Rotureau, D. Briand, N. F. de Rooij, Sens. Actuators, B 2006, 118, 263.

\section{Figures}

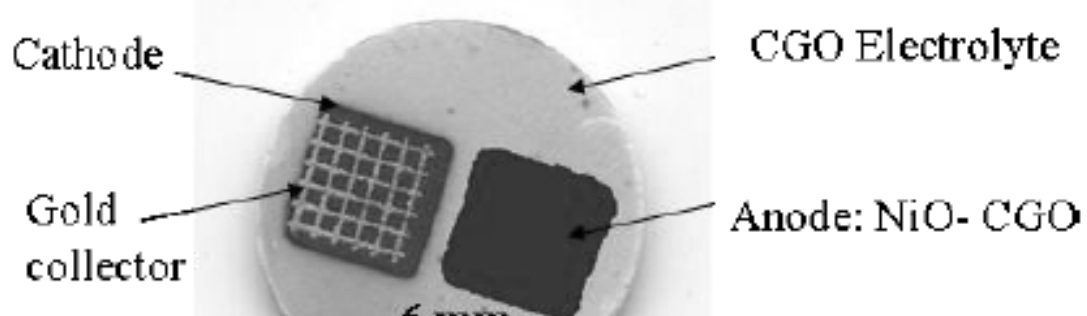

$6 \mathrm{~mm}$

Figure 1: SCFC prototype on GDC pellet with screen-printed electrodes.

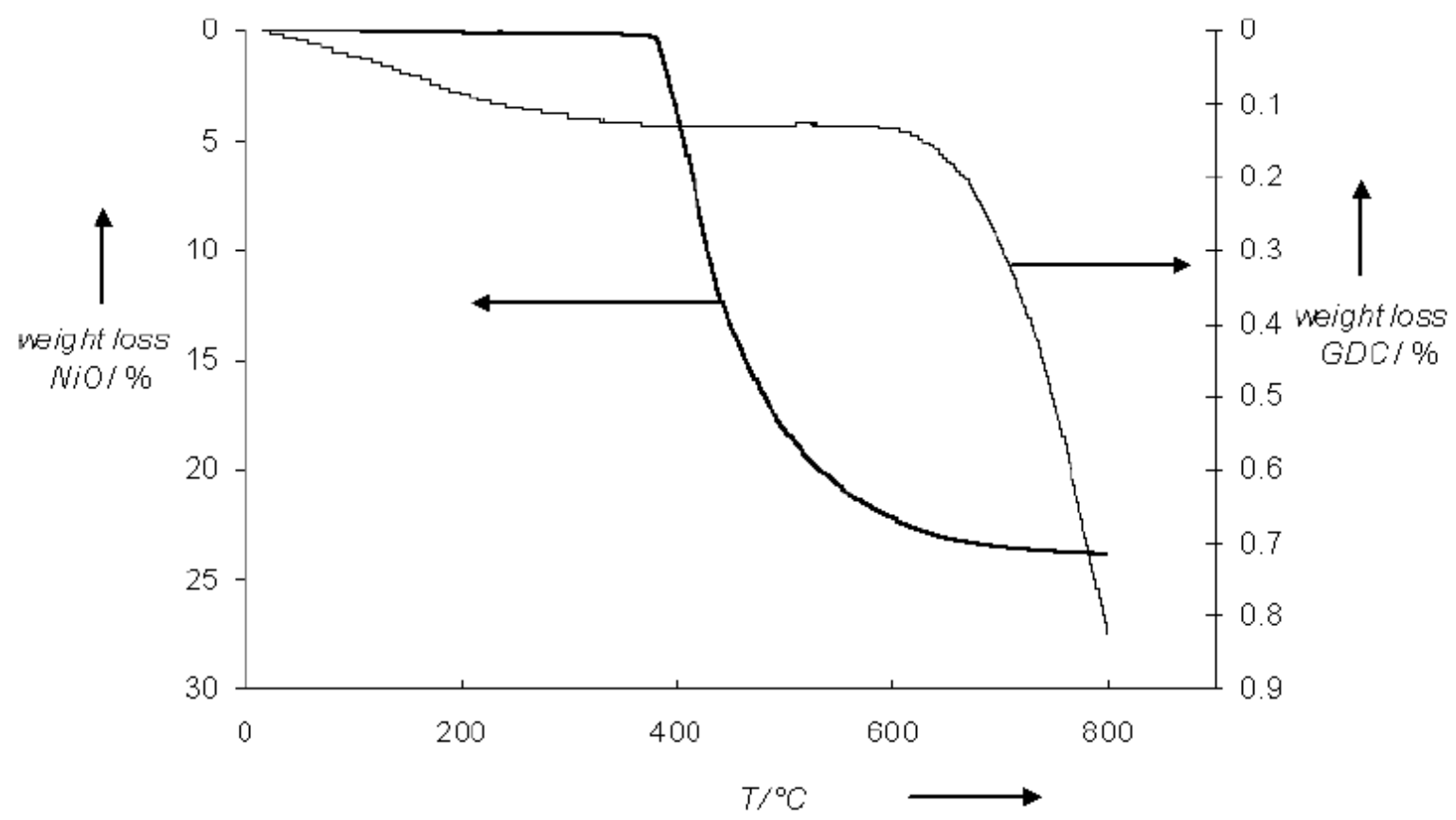

Figure 2: Thermogravimetric analysis of $\mathrm{NiO}$ and GDC powders under hydrogen (2\% in $\mathrm{Ar}$ ), temperature rising rate $10^{\circ} \mathrm{Cmin}^{-1}$. 
Fuel Cells, 2010, 10(4), 683-692, doi: 10.1002/fuce.200900146

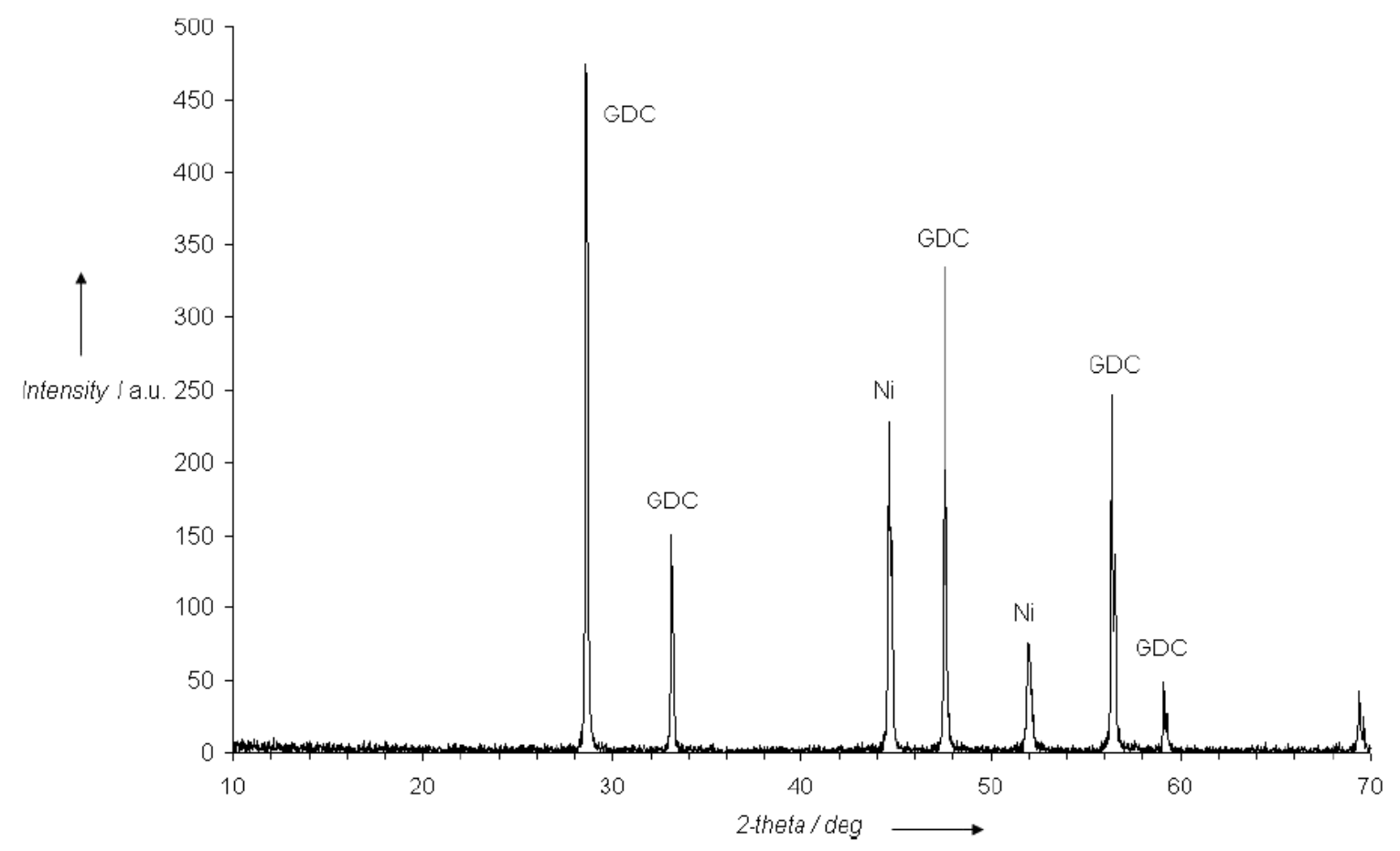

Figure 3: XRD pattern of NiO-GDC anode after reduction $600{ }^{\circ} \mathrm{C}-30$ min under hydrogen ( $2 \%$ in $\mathrm{Ar}$ ).

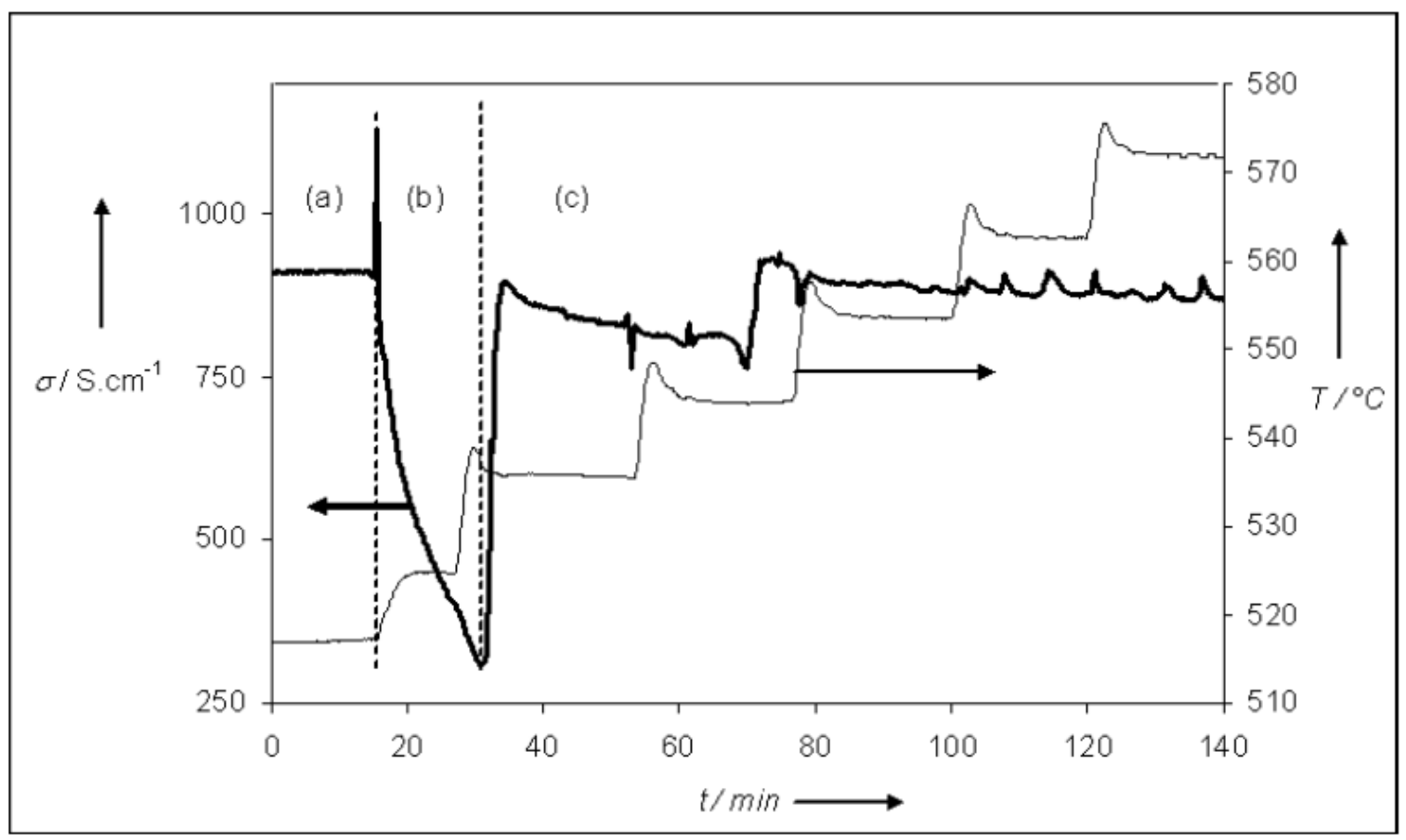

Figure 4: Ni-GDC anode conductivity in air-propane mixture $\left(\mathrm{C}_{3} \mathrm{H}_{8} / \mathrm{O}_{2}=0.66\right)$, vs. temperature. 


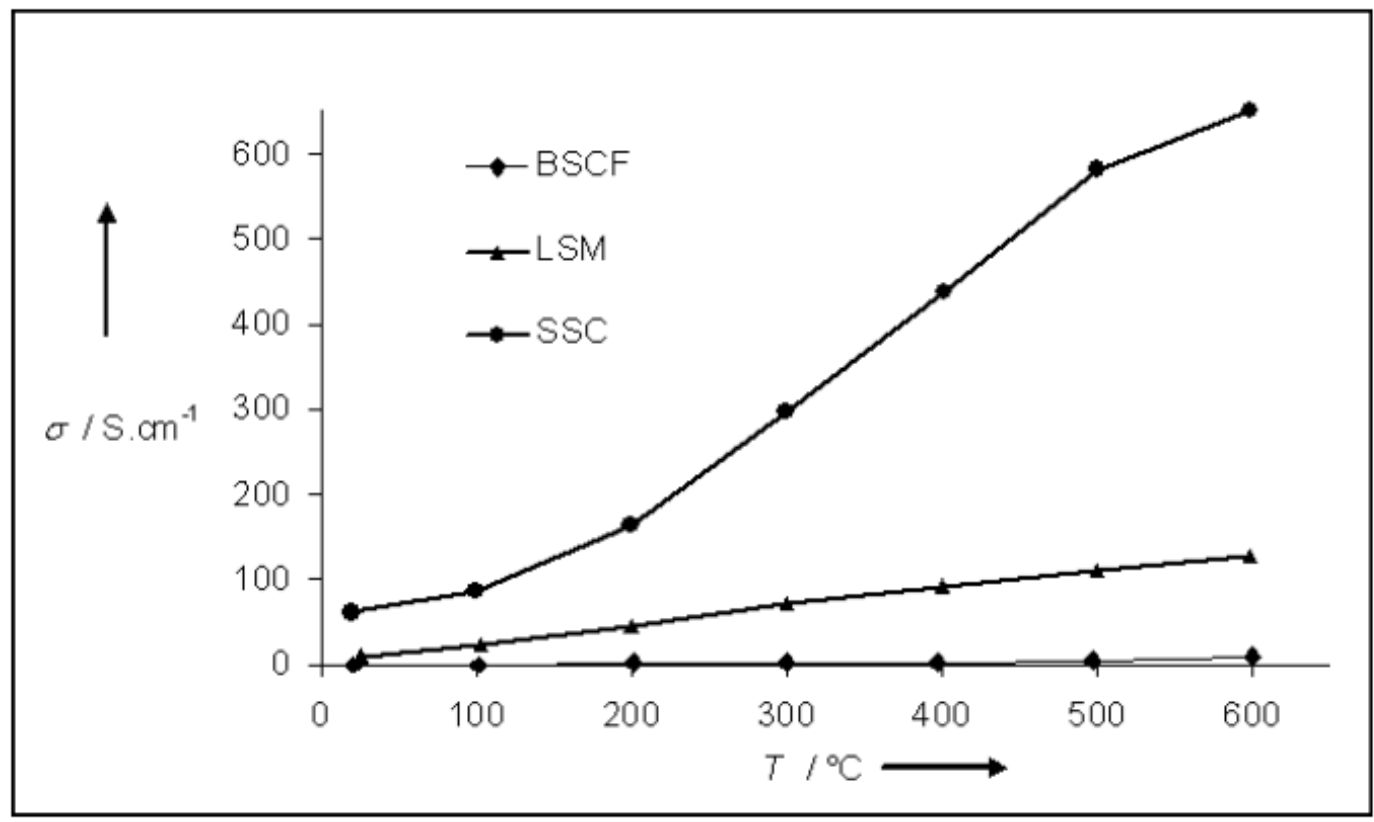

Figure 5: LSM, SSC and BSCF cathodes conductivity in air vs. temperature.

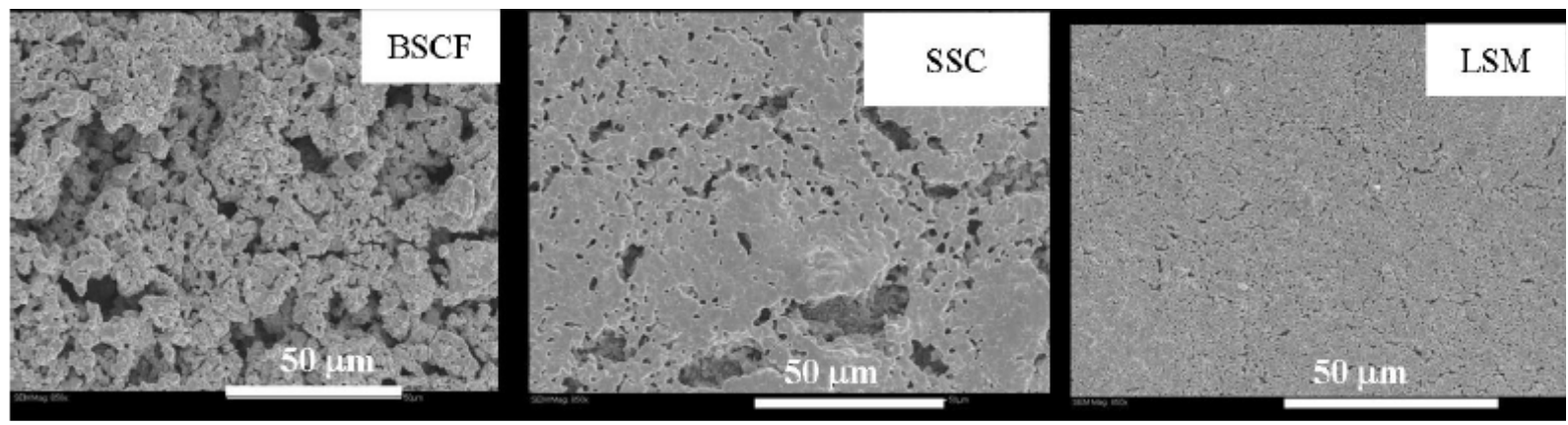

Figure 6: SEM of BSCF, SSC and LSM cathodes (as prepared layers).

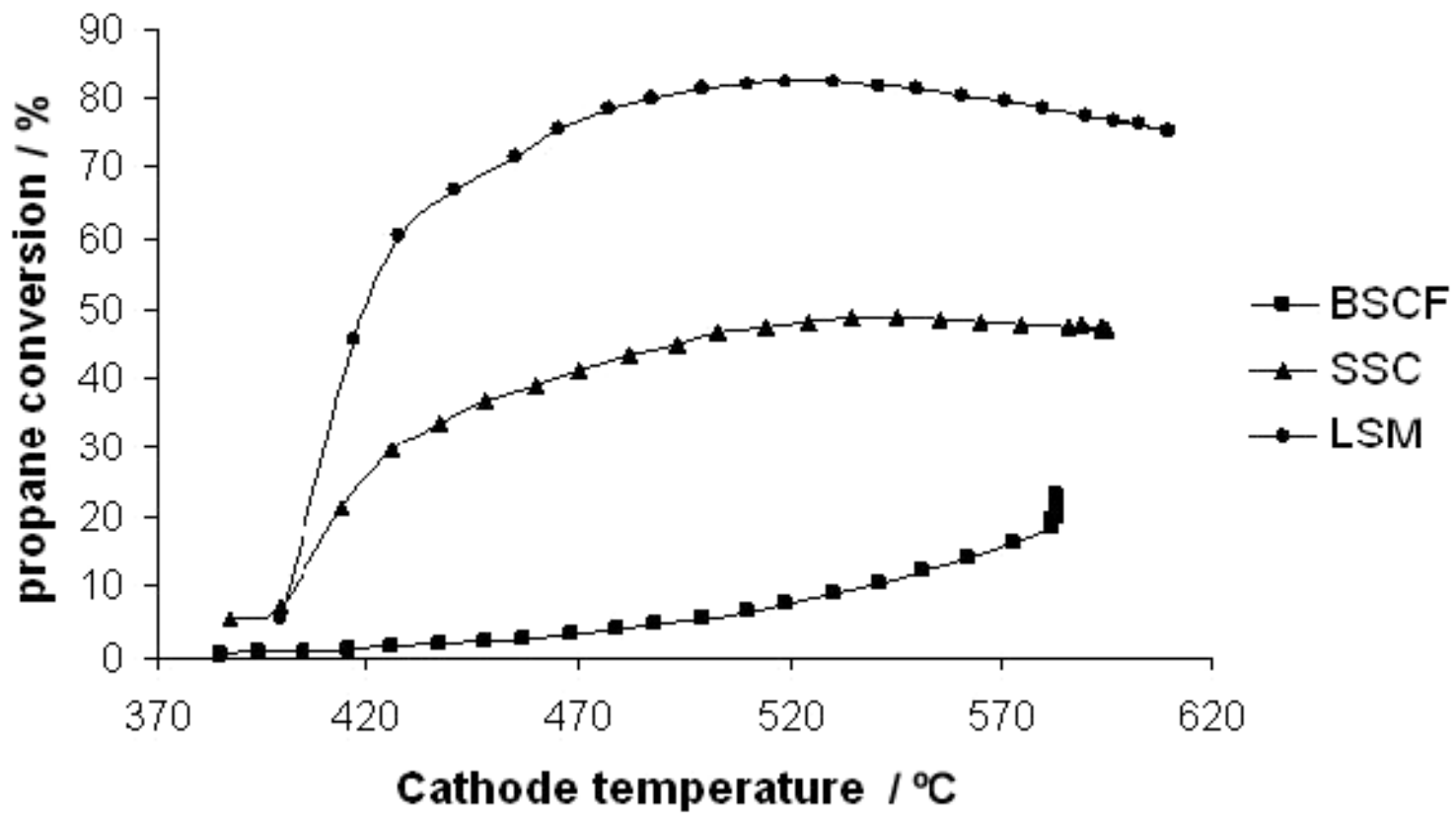

Figure 7: Catalytic activity measured as propane conversion rate with a $\mathrm{GGC}-\mathrm{MS}$, of BSCF, SSC and LSM cathodes (powders in a fixed bed reactor). 
Fuel Cells, 2010, 10(4), 683-692, doi: 10.1002/fuce.200900146

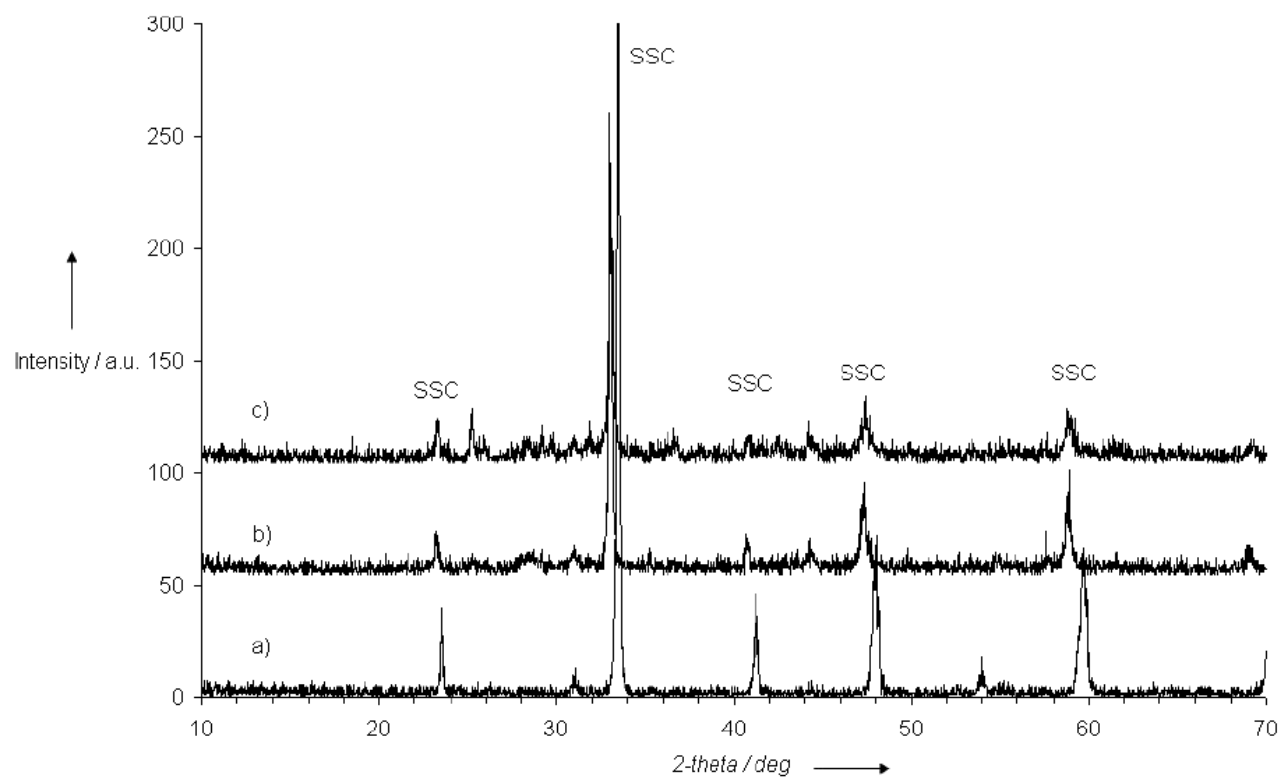

Figure 8: XRD patterns of SSC cathode (a) as prepared, (b) after reduction $600{ }^{\circ} \mathrm{C}-30$ min under $\mathrm{H}_{2}(2 \%$ in $\mathrm{Ar}$ ) and (c) after $\mathrm{C}_{3} \mathrm{H}_{8} / \mathrm{O}_{2}$ exposure at $630{ }^{\circ} \mathrm{C}$ during $3 \mathrm{~h}$.

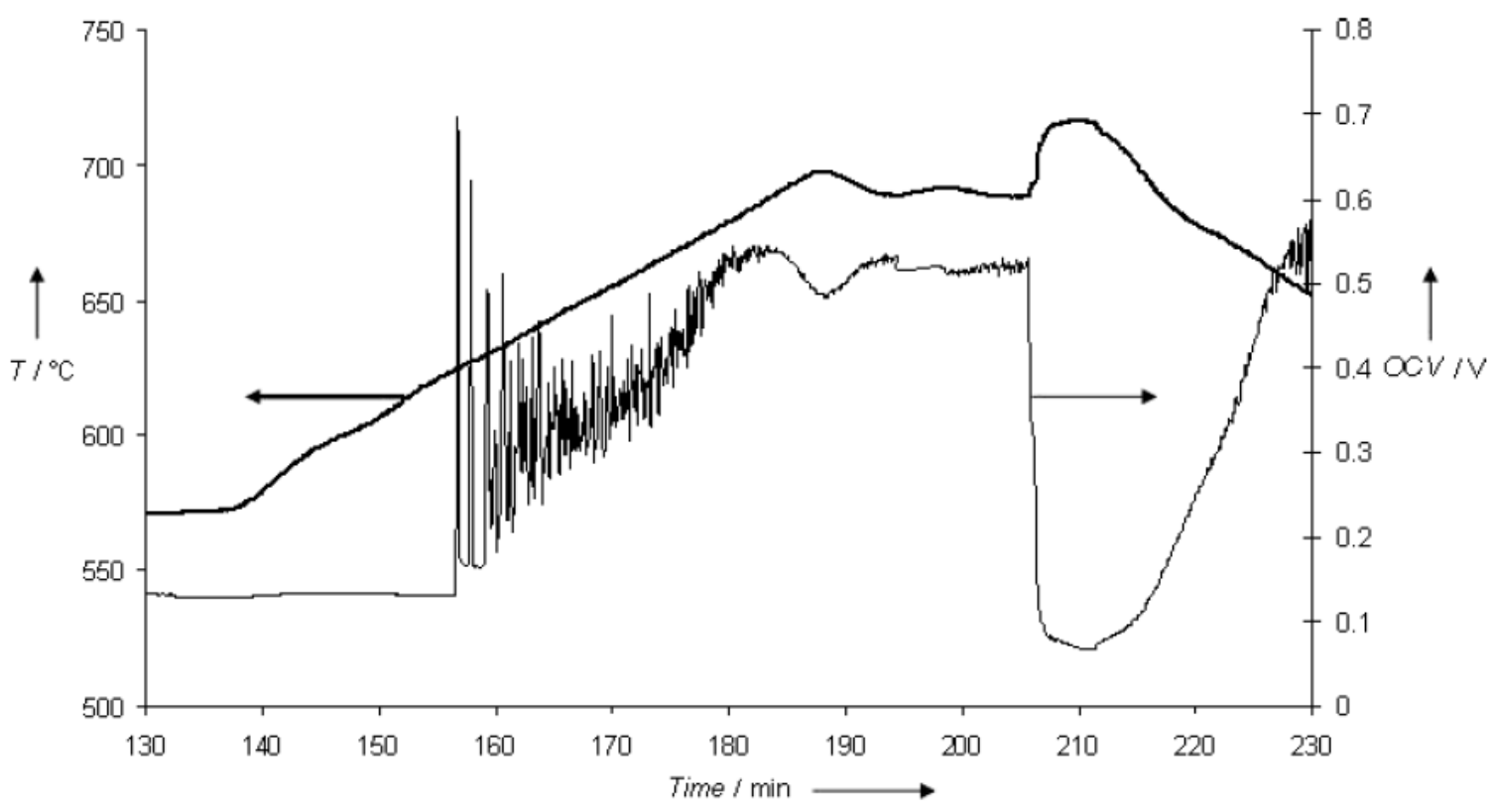

Figure 9: Open circuit voltage time dependence of a Ni-CGO/CGO/LSM SCFC under air-propane $\left(\mathrm{C}_{3} \mathrm{H}_{8} / \mathrm{O}_{2}=\right.$ $0.55)$, vs. time, with varying sample temperature. 
Fuel Cells, 2010, 10(4), 683-692, doi: 10.1002/fuce.200900146

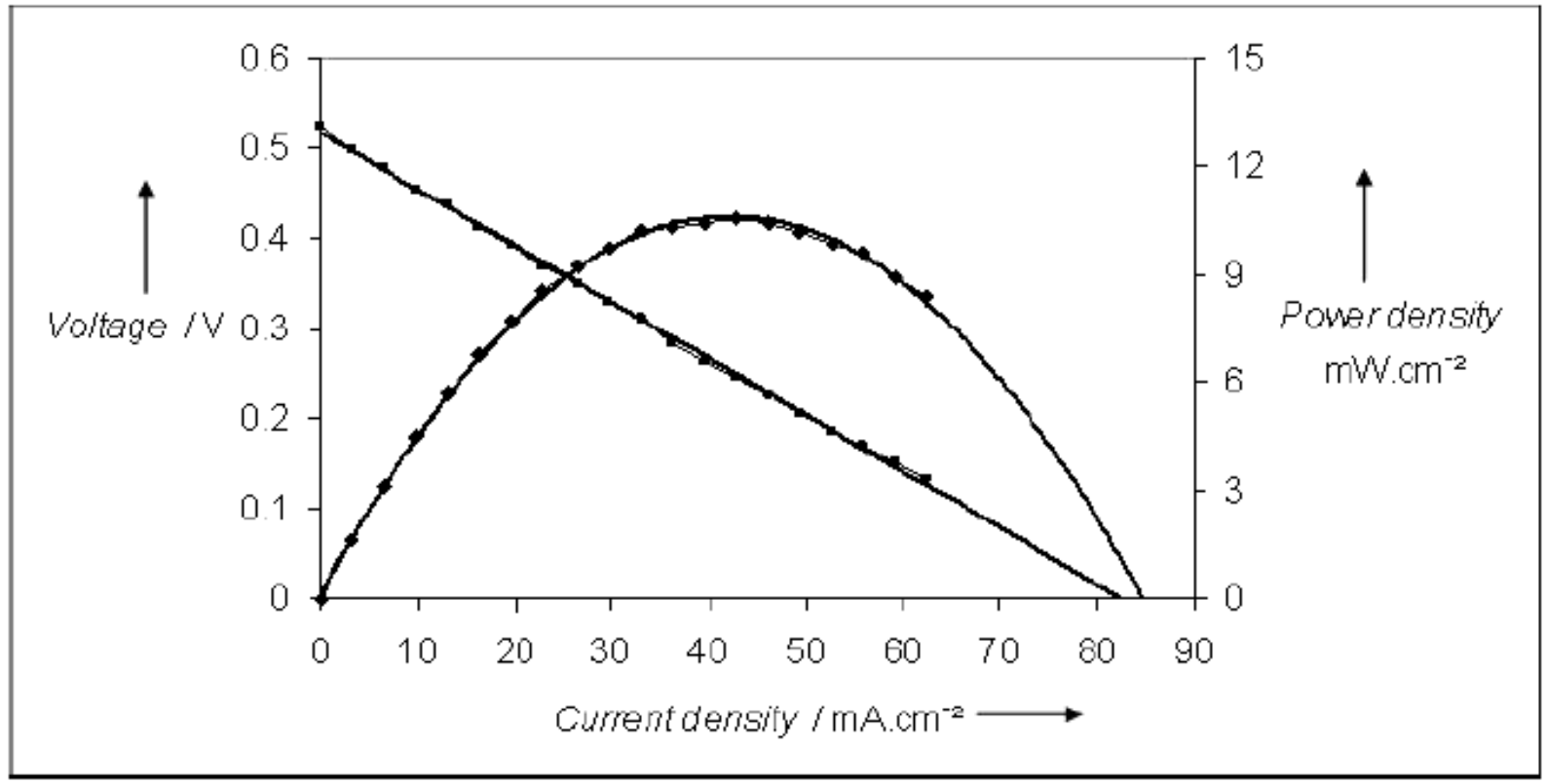

Figure 10: Voltage-current characteristic of a Ni-CGO/CGO/LSM SCFC at $700{ }^{\circ} \mathrm{C}$ (SCFC temperature) under air-propane $\left(\mathrm{C}_{3} \mathrm{H}_{8} / \mathrm{O}_{2}=0.55\right)$.

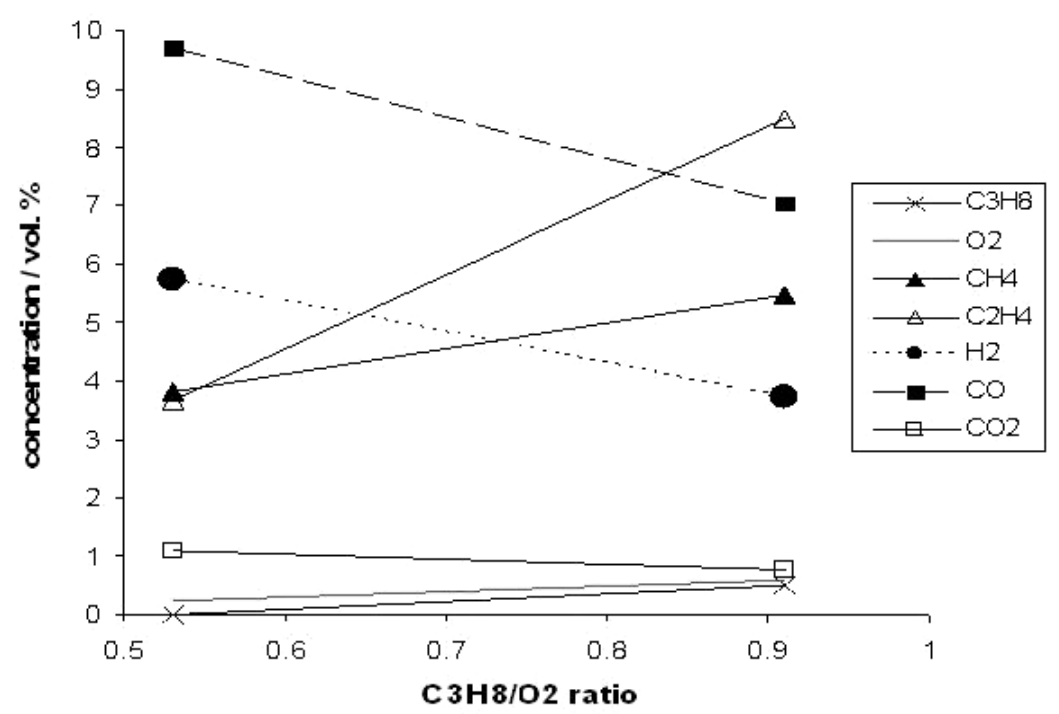

Figure 11: Influence of $\mathrm{C}_{3} \mathrm{H}_{8} / \mathrm{O}_{2}$ ratio on outlet gas composition, during SCFC test, at $620{ }^{\circ} \mathrm{C}$ with a total gas flow of $45 \mathrm{~L} \mathrm{~h}^{-1}$. 


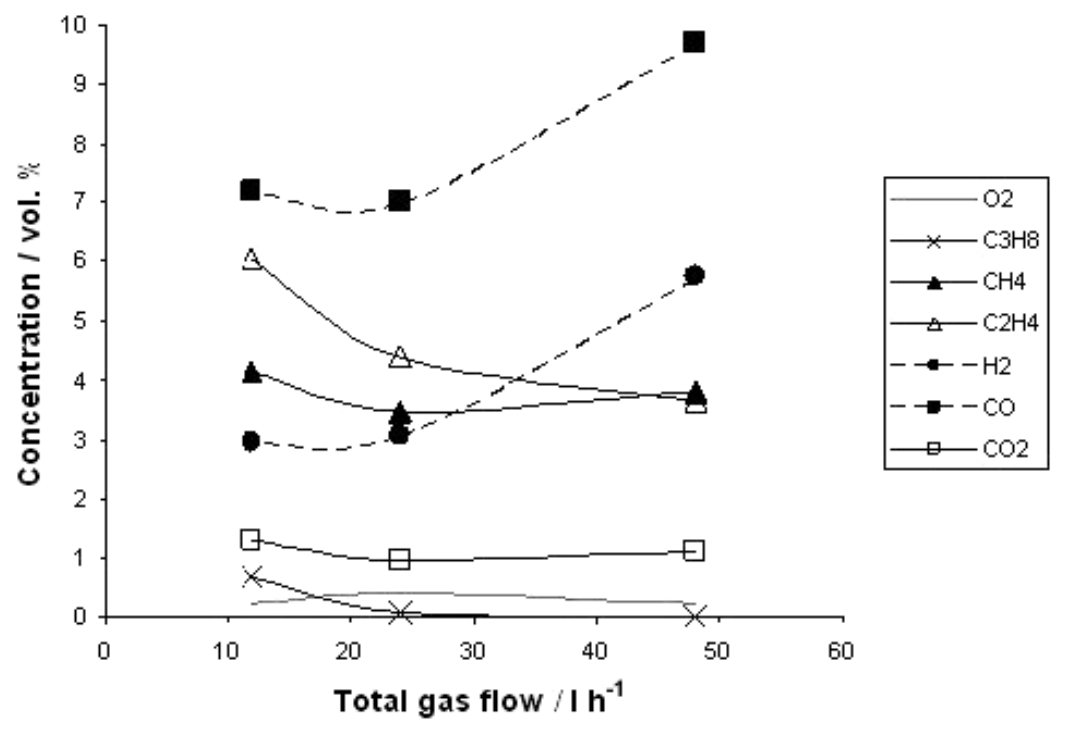

Figure 12: Influence of total gas flow on outlet gas composition, during $\mathrm{SCFC}$ test, at $620{ }^{\circ} \mathrm{C}$ with a $\mathrm{C}_{3} \mathrm{H}_{8} / \mathrm{O}_{2}$ ratio set at 0.53 .

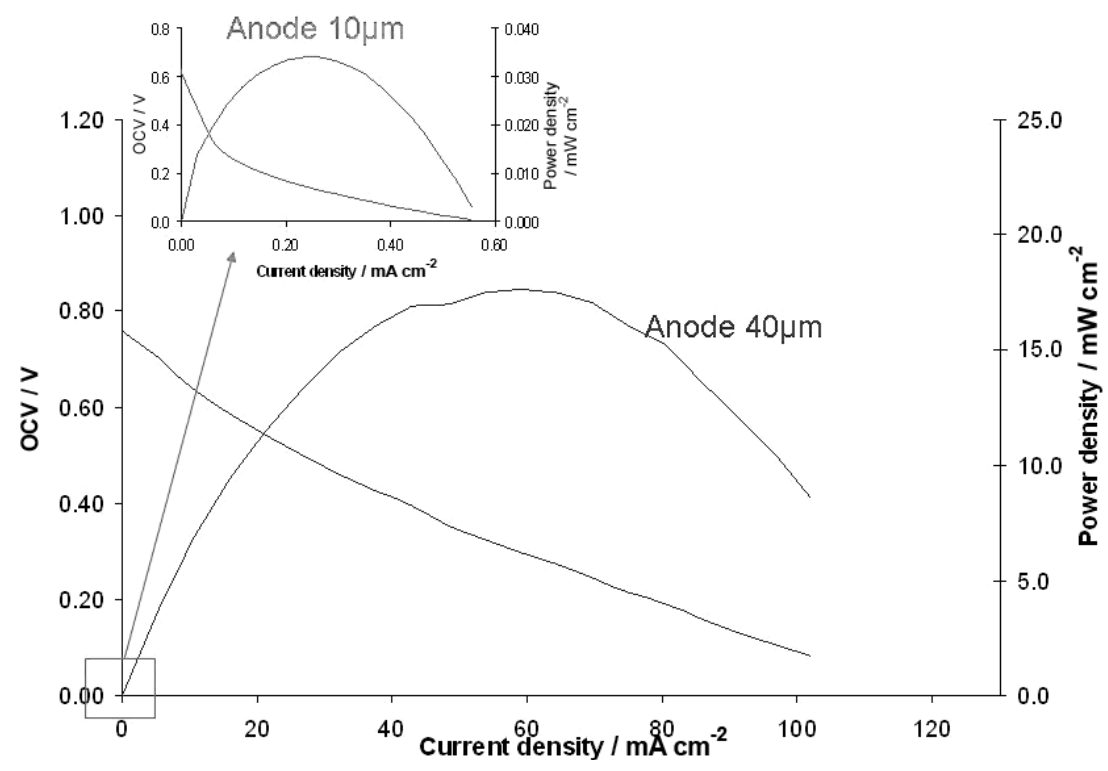

Figure 13: Voltage- current characteristic of a Ni-CGO/CGO/ LSM SCFC at $620^{\circ} \mathrm{C}$ (SCFC temperature) under air-propane $\left(\mathrm{C}_{3} \mathrm{H}_{8} / \mathrm{O}_{2}=0.53\right)$, with a total gas flow of $45 \mathrm{~L} \mathrm{~h}^{-1}$. Influence of anode thickness: $40 \mu \mathrm{m}$ in main curve, $10 \mu \mathrm{m}$ in insight.
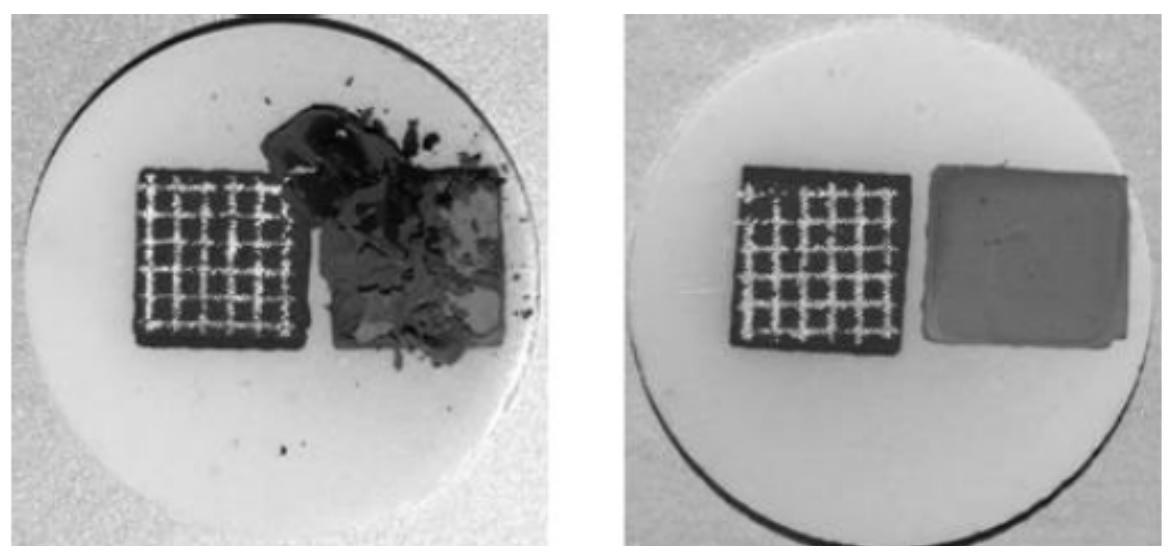

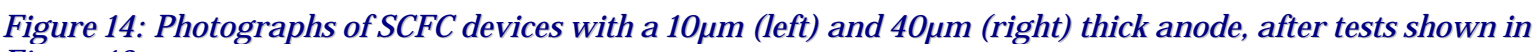
Figure 13. 